症例

食道ステントによる巨大気管一気管支食道㾞（全長 $13 \mathrm{~cm}$ ) に対寸る気管，気管支再建の 1 例

北信総合病院呼吸器外科, 同 外科*, 東京医科歯科大学大学院心肺機能外科学** 細田裕砥 石 政 幸* 藤 森 芳 郎* 五十嵐淳* 宮 本 英 雄* 砂 盛 誠**

われわれは食道癌術後（上行結腸再建術式）の良性狭窄に対して 2 回のステント留置 により巨大な気管一気管支食道瘦を形成した症例に対して気管一気管支の再建を行っ た.

胸腔内気管膜様部の全長が欠損し，膿胸を併発さらに気管内ステント突出による気道

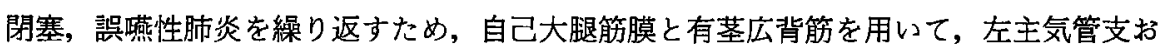
よび気管分岐部から，頸部気管移行部までの約 $13 \mathrm{~cm}$ にわたる気管一気管支の再建を行 った。大胧筋膜と広背筋により再建した気管膜様部は咳嗽反射にも協調し機能的にも優 れていた.

真引用語：食道ステント，気管一気管支食道瘦，気管再建術

\section{緒言}

食道手術後の再建食道の狭窄に対して，ステント留 置を余儀なくされる場合がある，食道の良性狭窄に対 するこのステント留置は効果的であるとの報告もみら れるものの, 重篤な合併症の報告もみられる ${ }^{122)}$. 瘦孔 の大きさによっては，気管支鏡的な好置や気管ステン 卜留置で軽快する例もあるが, 食道気管, 気管支掼は, 呼吸器感染が急速に進展し, 呼吸不全が進行するため, 必ずしも治療成績は良くないと考光られる ${ }^{3}$.

今回われわれの経験した症例は, 2 回にわたるステ ント留置により, 胸部気管膜様部が全長にわたり欠損 し, 食道 (上行結腸再建) と気管が共通管を呈してい た。この共通管に新たに膜様部を形成し, 気管一気管 支の再建に成功したので報告する.

$$
\text { 症例 }
$$

症例：58歳, 男性.

主訴：呼吸困難.

既往歴：椎間板へルニア.

家族歴：特記すべきことなし。

現病歴: 1999年 2 月に検診で胃癌, 食道癌が発見さ

2001 年 10 月 3 日受付 2002 年 4 月 2 日採用

〈所属施設住所〉

广 $383-8505$ 中野市西 1-5-63
れた.1999年 4 月に食道抜去, 胃全摘, 後緹隔経路で 上行結腸による食道再建を行った。術後 I 週目で門歯 列より $24 \mathrm{~cm}$ の位置の頸部食道結腸吻合部に縫合不全 を併発，その後約 2 カ月で食道入口部より $3 \mathrm{~cm}$ の位 置（門歯列より $23 \mathrm{~cm}$ ) から全長約 $2 \mathrm{~cm}$ にわたる直径 $3 \mathrm{~mm}$ 程度の狭窄と閏歯列より $33 \mathrm{~cm}$ の位置に $3 \mathrm{~cm}$ にわたる直径 $5 \mathrm{~mm}$ の狭窄をきたした。 2 籄所の狭窄 に対して，その後約11力月間に25回もの食道フジー插 管による搪張術を繰り返し，狭窄解除を試みたが門歯 列より $23 \mathrm{~cm}$ の食道狭窄は改善しないため, 2000 年 7 月にcovered expandable metaric stent (Ultara flex $17 \mathrm{~mm}, 10 \mathrm{~cm})$ を留置した。 その後は門歯列より 33 $\mathrm{cm}$ の位置の食道狭窄は遺残していたものの自宅での 生活が可能であったが，2000年12月より，肺炎を繰り 返すようになり再入院となった. 当初, 誤喂性肺炎と して, 保存的に治療していたが, 一進一退を繰り返し, 2001年 2 月に気管支ファイバー検查で, 留置ステント の上縁の高さに約 $3 \mathrm{~cm}$ 径の気管食道瘦が確認され, 気管内にステントの突出を認め多量の唾液が気管へ流 入していた。このため, 気管食道㿉による気道への㕰 液流入を減らす目的で，2001年 3 月にさらにステント 留置を行った. 追加留置されたステントは, covered expandable metaric stent (Ultara flex $18 \mathrm{~mm}, 10 \mathrm{~cm}$ ) で, 最初のステントの内沿に一部重なるように $2 \mathrm{~cm}$ 


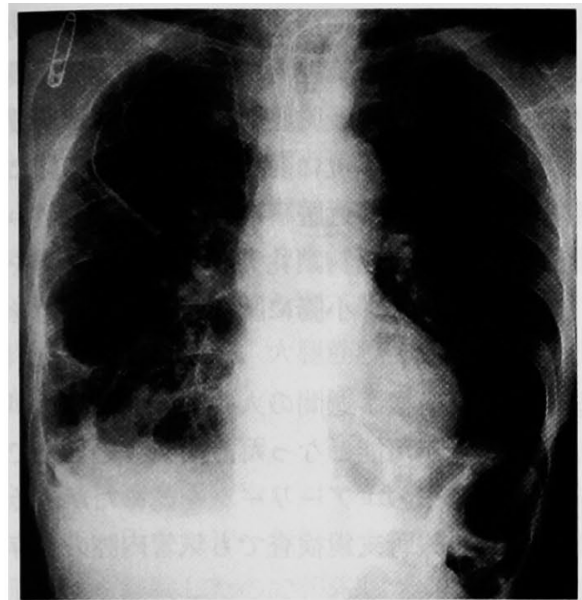

図 1 術前胸部 X 線写真：右肺の広匴な浸潤 影と胸水の貯留を認める.

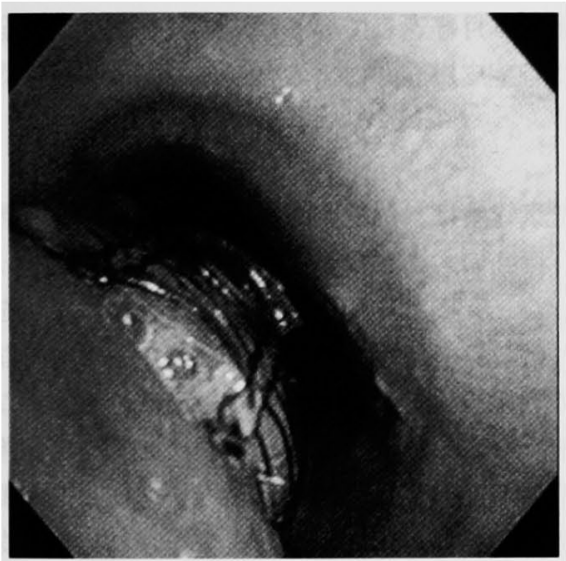

图 2 術前気管支ファイバー所見：気管膜様 部からステントが露出している。

ほど頭側よりに留置された、ステントの追加留置によ ク一時的に気道への唾液流入は改善したが，約 2 週間 でステントのほほ全長が気管内に脱出した。このた め気道閉塞が進行し、2001年 4 月より気管内插管を行 い,人工呼吸器装着となった。このときの胸部 X線検 查では，右肺炎と胸水の貯留を認める(図 1 )。手術前 の気管支ファイバー検查では，胸腔内気管膜様部は圧 迫壞死により消失し，気管内腔には食道ステントの外 壁が認められた（図 2)。また左主気管支膜様部もステ ントの露出を認めた。胸部 CT では，食道ステントは 気管膜様部から気管内に突出していた（図 3). 胸部 CT の気管支鏡モード再構成画像でも気管内腔に突出 する食道ステントの模樣が明膫に描出された（図 4 ）.

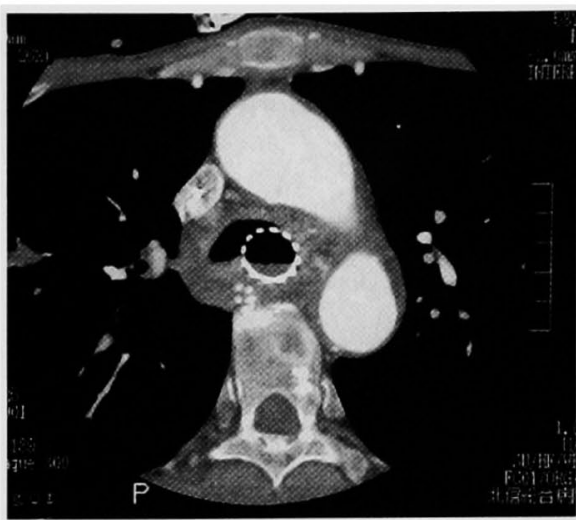

図 3 術前胸部 CT 所見：気管と食道は胸腔内 の全長にわたり共通管状になっており，内部 にステントが認められる。

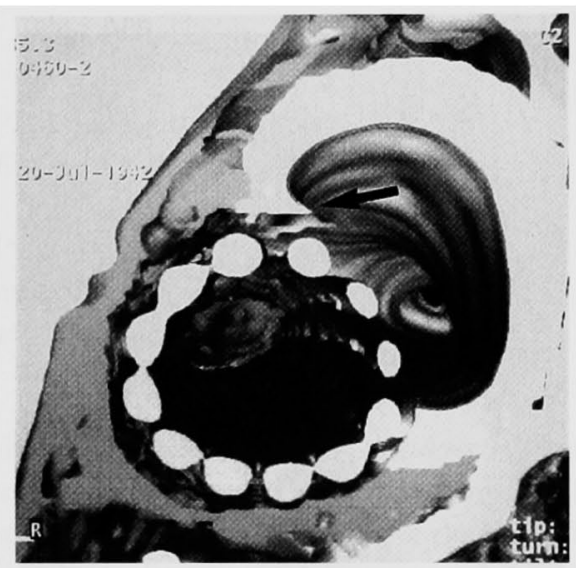

図 4 気管支鏡モード CT 画像所見：気 管内 に突出するステントが描出されている，左 主気管支が圧排閉塞している (知).

以上の経過により，気管の再建を目的として，2001年 5 月17日に手術を施行した。

手術は仰臥位で，左大腿筋膜の採取を行った。大腿 筋膜は，気管一気管支の再建にさいして粘膜の代用と して気密性を保つことができるようにするため，18 $4 \mathrm{~cm}$ の大きさで採取した。大腿筋膜採取後, 体位を左 側臥位に変換し，右後側方切開を行い，右広背筋を第 12肋骨の高さまで，有荎で採取した，開胸は，第 4 助 骨床で行ったが，肺炎を繰り返し，膿胸も併発してお り，非常に強固な癒着を認めた。癒着を剥離し，気管 に到達した，気管膜様部側に小切開を加え，気管内に 突出したステントにより挿入困難であったダブルルー メン気管内チューブを，気管内腔から用手的に左主気 


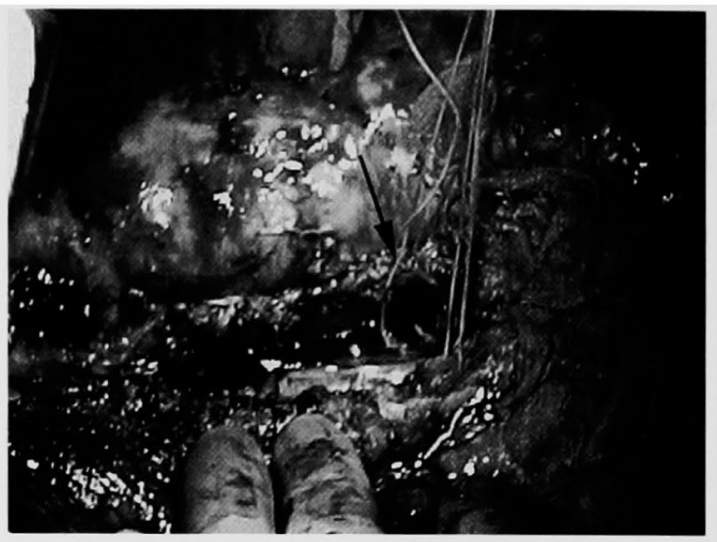

図 5 術中所見：ステントは食道および気管膜様部を破 壊し内腔に浮いた様に存在していた。矢印はステントの 一部摘出後の断端を示す。

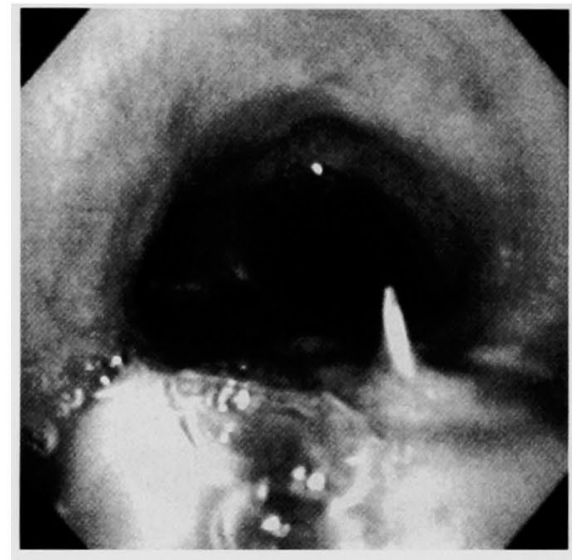

図 6 術後気管支鏡所見 : 大腿筋膜は一部欠 損したものの，広背筋の補強により十分気 管内腔が保持されている。広背筋により補 強された膜様部は咳濑反射に追随する。

管支に誘導し，分離肺換気が可能となった。ついで食 道気管周囲の線維性結合組織に広く切開を加えステン 卜を露出した。ステントは，食道と気管支の共通管内 に中に浮いたように存在し，上行結腸による再建食道 粘膜は全く存在せず，結合織の管状構造物に置換され ていた（図５）。ステントは長軸方向の中央で横断し， 上部，下部それそれ鈍的に别離し摘出した。ステント 摘出後は，気管は，軟骨部のみが平板状となっていた。 ステントの尾側の食道は狭窄し痏痕化していたが，気 管分岐部下, 約 $3 \mathrm{~cm}$ から明瞭に確認されたため,これ を縫合閉鎖し，盲端とした。ついであらかじめ採取し ておいた大腿筋膜をトリミングし，十分に気管内腔を
確保できるように気管に縫着した。ついで第 2 肋間を 経由した有茥広背筋を胸腔内に誘導し，大腿筋膜の上 に縫着した。気管再建後胸腔ドレーンを 3 本留置し, 閉胸した．体位を仰臥位に変換し，頸部横切開にて食 道を露出し，胸腔内の近医盲端に可及的に近づいた位 置で食道を切断し，左胸鎖乳突筋の前方に外瘻を造設 した。さらに開腹し，小腸に腸瘦をおき，手術を終了 した.

術後経過：手術後 1 週間の人工呼吸を用したが，そ の後は自発呼吸が可能となった。術後 3 週目までは気 管縫合部から若干のエアーリークを認めたが，その後 は順調に経過し気管支鏡検査でも気管内腔の開存は良 好である(図6).

なお患者は食道気管瘦発症前より指摘されていた右 上皮小体腫瘍の摘出術を通常の気管内挿管による全身 麻酔で行い，気管形成術後 3 力月で一時退院した。現 在術後10力月経過しているが，気管一気管支に全く問 題なく有茥皮䒄筋弁による食道の再建術式の待機中で ある。

\section{考察}

食道気管瘦は，治療困難な例が多くその発症機転や 部位，瘦孔の大きさなどにより治療方針は異なってい る.しかし究極は外科治療ができる場合，これを行わ なければ救命できない，最近ではステント留置などを はじめ内視鏡的治療も含め様々な治療の工夫がなされ ている，しかしながら本症例の様にステント留置によ る気管膜様部が全長にわたり欠損状態になった場合の 手術報告はない.また食道と気管ならびに気管支が交 通した場合，全身状態は不良となり治療は必ずしも容 易ではない3)4.気管の再建が長距離にわたる場合は非 常に困難で，予後は不良である，気管再建に食道壁を 用い大きな瘦孔を閉鎖し 2 期的に胃管で食道を再建し た報告らもあるが, 本例では胃, 食道とも手術で切除さ れており，自家再建材料は限られていた。食道ステン トによる気管食道㾇に対して広背筋弁で修復した例で も，比較的小さい瘦孔に対しては有効と考えられ $3^{1 / 3)}$. 本例の様に胸腔内気管膜様部の全長にわたる瘦 孔では再建缄器の選択が重要である。おそらく有荃広 背筋のみでは平板状に広がった気管に内腔を形成でき なかったと考えられる。遊離大腿筋膜を使用し軟骨部 に十分張力をかけることができたため術後の気管の形 状を保つことができたと考えている。

本症例の場合, 胸腔内食道も摘出後で, 上行結腸に よる食道再建後の気管瘦を発症しており不利な条件下 
ての気管再建となった，大腿筋膜を用いた理由は，採 取が容易であり，十分な厚みと強度があることによる。 広背筋の充填法は腸胸に対する手術において汎用され る方法であり，気管膜様部のを形成した大腿筋膜の補 強および維隔膿場腔の充填材料として用いた。結果的 には咳嫩反射にも追随する上，肉芽形成もなく，順調 に経過している. 機能的な面, 感染胸腔の充填, 十分 な筋肉量から考えても，大腿筋膜と広背筋による気管 膜様部再建は有用であったと考えている。

$$
\text { 結語 }
$$

食道癌術後吻合部狭窄に対するステント留置により 形成された，巨大気管一気管支食道漊に対する広範な 気管形成術を経験したので報告した。

$$
\text { 文献 }
$$

1) Schowengerdt CG : Tracheoesophageal fistula caused by a self-expanding esophageal stent.
Ann Thorac Surg $67:$ 830--831, 1999

2) Boulis NM, Armstrong WS, Chandler WF, et al : Epidural Absecess : A delayed complication of esophageal stenting for benign stricture. Ann Thorac Surg 68:568-570, 1999

3) Couraud L, Ballester MJ, Delaisement C: Acquired tracheoesophageal fistula and its management. Semin Thorac Cardiovasc Surg $8: 392-399,1996$

4）田川努, 伊藤重彦, 井手誠一郎他：腐食性食道 狭䂟に対し expandable metallic stent を使用し 食道気管支瘦を形成した 1 例。日胸外会誌 45 ： 1044-1048, 1997

5) Galan G, Tarrazona V, Soliveres J, et al: Trachoplasty in large tracheoesophageal fistula. Ann Thorac Surg 68: 1071-1072, 1999

\title{
TRACHEOPLASTY IN A GIANT TRACHEOESOPHAGEAL FISTULA CAUSED BY A SELF-EXPANDING ESOPHAGEAL STENT-A CASE REPORT-
}

\author{
Hiroshi HOSODA, Masayuki TOISHI*, Yoshiro FUJIMORI* \\ Jun IGARASHI*, Hideo MIYAMOTO* and Makoto SUNAMORI** \\ Division of Thoracic Surgery and Division of Surgery*, Hokushin General Hospital \\ **Department of Thoracic and Cardiovascular Surgery, Tokyo Medical and Dental University
}

A man who had previously undergone an esophagectomy for squamous cell carcinoma and total gasterectomy for adenocarcinoma of the cardia of the stomach had had his esophagus replaced with a colon graft. He had undergone 25 bougie treatments for repeated benign strictures of the reconstructed esophagus. After that, benign stricture was treated with a self-expanding metal stent. Five months later the lower part of the stent eroded though the esophagus into the trachea and left main bronchus, forming tracheoesophageal and bronchoesophageal fistulas.

A second self-expanding metal stent was placed to cover the fistulas. Two weeks later the whole collection of stents eroded through the esophagus into the trachea. The membranous portion of the thoacic trachea was completely destroyed by the metal stent in the reconstructed esophagus, forming a giant $13 \mathrm{~cm}$ fistula. He developed severe thoracic empyema and aspiration pneumonia, necessitating surgery for the tracheoesophageal fistula. The 2 stents and eroded esophagus (colon graft) were resected. The tracheoesophageal fistula was repaired with a free graft of the left fascia lata and the right latisumus dorsi muscle flap. Patch repair with fascia lata and reinforcement with the latisumus dorsi muscle flap were successful. A temporry esophagostomy for proximal esophagus and jejunostomy were made. 